Ročník XIX (2017), Číslo 3-4, s. 323-328/ Volume XIX (2017), Issue 3-4, pp. 323-328

(c) Mezinárodní politologický ústav / International Institute of Political Science

DOI: $10.5817 / C E P S R .2017 .34 .323$

\title{
Přemysl Rosůlek: Albánci a Makedonská republika (1991-2014)
}

\author{
Praha: Libri, 2015. 395 s., ISBN 978-80-7277-526-2
}

MiCHAL HRUŠík ${ }^{1}$

Publikácia Přemysla Rosůlka je primárne zameraná na vývoj vzt’ahov medzi väčšinovým etnikom slovanských Macedóncov (hoci sám autor sa tomuto označeniu snaží skôr vyhýbat') a najväčšou etnickou menšinou macedónskych Albáncov. Ide o vel'mi vítaný príspevok $\mathrm{k}$ analýze aktuálnych politických i bezpečnostných výziev $\mathrm{v}$ regióne západného Balkánu, a to $\mathrm{z}$ dvoch hlavných dôvodov. Po prvé, tematike nástupníckych štátov na území niekdajšej Socialistickej federatívnej republiky Juhoslávie (SFRJ) je síce venované vskutku obrovské množstvo monografií lokálnych, anglosaských, ale tiež českých autorov, väčšina $\mathrm{z}$ nich sa však zameriava na historické súvislosti a následne vývoj v rokoch 1991 - 1995, v prípade Kosova potom do r. 1999; spracovanie vývoja v nedávnej minulosti s dôrazom na budovanie štátu a príspevok medzinárodného spoločenstva však už takým častým vonkoncom nebýva. Po druhé, vzhl’adom na komplikované vzt'ahy s väčšinou svojich susedov, slabšie národné povedomie a štátotvornú tradíciu v porovnaní s okolitými krajinami, ${ }^{2}$ ako aj prítomnost' signifikantnej a regionálne koncentrovanej národnostnej menšiny s úzkymi cezhraničnými väzbami na Albánsko a Kosovo, je Macedónsko považované za potenciálne zrejme najrizikovejšiu krajinu $\mathrm{v}$ regióne, pričom $\mathrm{v}$ porovnaní napr. $\mathrm{s}$ Bosnou a Hercegovinou, kde môžeme hovorit' primárne o hrozbách politického charakteru, je v Macedónsku akútnejšie i bezpečnostné riziko.

1 Vel'vyslanectvo Slovenskej Republiky v Belehrade, Bulevar umetnosti 18, 11070 Belehrad, Srbsko / The Embassy of the Slovak Republic in Belgrade, Serbia. E-mail: michal.hrusik@mzv.sk. ${ }^{2}$ Konštatuje to aj samotný autor, ktorý sa odvoláva na M. Hrocha (1999) a jeho kategorizáciu balkánskych národov do troch skupín podl'a vytvárania a udržiavania tzv. kolektívnej pamäte. Podl'a tejto teórie patrí macedónsky národ do tretej skupiny, pre ktorú je o.i. „typická absencia literárneho jazyka, ako aj tvorba v tomto jazyku“ (str. 47). Dôkazom je aj kodifikovanie kompletného macedónskeho pravopisu až v r. 1950 (str. 101). Okrem toho autor pre porovnanie uvádza aj často dost' extrémne znejúce teórie macedónskych nacionalistov, podla ktorých je macedónsky národ priamym etnickým potomkom antických Macedóncov z čias Alexandra Vel'kého (str. 93), čo podnecuje frustráciu Grécka, ale tiež albánskej menšiny. 
Publikácia je formálne rozdelená na šest' častí, reálne však môžeme hovorit' o dvoch častiach - teoretickej, ktorá sa zaoberá rôznymi modelmi nacionalizmu a skúma okolnosti vedúce ku konfliktom etnického charakteru (venovaných je jej 55 strán, čiže približne šestina knihy), a empirickej, resp. deskriptívno-analytickej, v ktorej autor poskytne kratší historický exkurz vývoja širšieho macedónskeho regiónu, a následne popisuje udalosti $\mathrm{v}$ krajine od získania nezávislosti Macedónska. Hlavným prínosom knihy je jednoznačne jej druhá čast', a zároveň jedným z jej hlavných nedostatkov - ktorý sa bohužial' vel'mi často vyskytuje pri podobnom type monografií - je takmer absentujúce prepojenie medzi teoretickou a empirickou čast'ou. Priestor venovaný teoretickej časti pritom považujem za dostačujúci, a autor tu prináša niekol'ko zaujímavých modelov hodných našej pozornosti. Za spomenutie stojí napr. model, ktorý vychádza z teórie J. Marka (str. 58) pre zabezpečenie optimálneho pomeru medzi jednotlivými pólmi trojuholníku identita - rovnost' - rozdielnost', či analýza podmienok ovplyvňujúcich pravdepodobnost' secesie $s$ ohl'adom na obavy $z$ existujúceho štátu a dôveru vkladanú do secesie podl’a S. Diona (str. 60). Je však škoda, že v empirickej časti sa k žiadnemu z uvedených modelov autor nevracia a nepracuje $\mathrm{s}$ nimi - automaticky tak pred čitatel’om vyvstáva otázka, či nie je teoretická čast' v knihe iba nevyhnutnou formalitou. A hoci je napr. Dionov model primárne určený pre analýzu „zakorenených demokraciî", dal by sa aplikovat’ aj na súčasné Macedónsko, kde boli obavy z existujúceho štátu u albánskej menšiny $\mathrm{v}$ rôznych obdobiach vysoké, dôvera vkladaná do secesie však bola aj s prihliadnutím na požiadavky formulované UÇK (ktoré odtrhnutie albánskych regiónov nepredpokladali) otázna. Autor spomína konkrétne príklady v prípade modelu teritoriálnych požiadaviek od S. Wolffa (str. 62), bližšie však už nevysvetl'uje, prečo patria Republika Srpska, moslimovia v Sandžaku a Albánci v Macedónsku do troch rôznych kategórií - o takomto zaradení, ked’ sa u jednotlivých príkladov rozlišujú (ne)iredentistické a (ne)secesionistické požiadavky, sa pritom dá určite diskutovat' a je škoda, že konkrétna argumentácia tu chýba. Podkapitola Teórie nacionalizmu a Balkán je napríklad spracovaná vel’mi dobre a zároveň poskytuje návod, ako vhodne skíbit' teóriu s empíriou, bohužial' sa však obmedzí iba na historický vývoj. Rosůlek tu však správne uvádza, že jedným z klúčových dôvodov vlastnej vývojovej trajektórie pre nacionalizmus balkánskych národov bola absentujúca industrializácia Osmanskej ríše, pričom „prevažovala...fragmentácia spoločnosti do uzatvorených celkov a komunít“ (str. 41). Dá sa tak skonštatovat', že autor tu nedostatočne využil ponúkané príležitosti a nepristúpil $\mathrm{k}$ prepojeniu teoretických modelov na praktickú čast', čo sa v niektorých kapitolách venovaných požiadavkám albánskej komunity a reakciám macedónskej väčšiny často žiadalo.

V úvode si autor kladie dve klúčové otázky - 1) aké boli príčiny konfliktu medzi macedónskymi bezpečnostnými silami a ozbrojenými skupinami etnických Albáncov v r. 2001 a 2) aké sú perspektívy mierového spolužitia medzi 
Macedóncami a Albáncami v krajine. Prvá otázka je vel’mi podrobne spracovaná v podstatnej časti knihy (kap. 8 a 9), pričom čitatel' sa môže oboznámit' s dôkladne vypracovaným záznamom o priebehu konfliktu vychádzajúcim i z dostatočne zastúpených primárnych zdrojov. Ohl’adom druhej otázky je autor skôr pesimista, ako konštatuje už v samotnom úvode - „Implementácia jednotlivých bodov (Ohridskej rámcovej dohody) ...nie je bezproblémová...svoju rolu zohráva i vyhlásenie nezávislosti Kosova i grécke veto voči macedónskemu členstvu v NATO a zahájeniu rozhovorov s EÚ“" (str. 19).

Čast' venovaná histórii je spracovaná na dostatočnej úrovni - je jej venovaný postačujúci priestor, aby čitatel, doteraz nie príliš oboznámený s dejinným vývojom v juhovýchodnej Európe, pochopil motivácie jednotlivých aktérov, ale zároveň si pre seba „neuzurpuje“ významnejšiu čast’ diela a slúži presne na to, čo je potrebné, a síce pochopenie hlavnej časti monografie venovanej súčasnosti. Rosůlek tak napr. vel'mi trefne konštatuje, že významným medzníkom pre novodobý vývoj macedónskej štátnosti bola revízia Sanstefanskej zmluvy, ktorá zamedzila včleneniu Macedónska do vznikajúceho nezávislého Bulharska, pričom - pokial by zmluva zostala $\mathrm{v}$ platnosti - $\mathrm{s}$ najväčšou pravdepodobnost'ou by došlo $\mathrm{k}$ úplnej asimilácii macedónskeho živlu a splynutiu s bulharským národom (str. 98). Podobne tak si všíma vel'mi komplikovanú etnickú štruktúru obyvatel'stva na predmetnom území, ktoré je „kotlom nekonečného ret'azca kombinácií a permutácií etnických a národnostných identít...a jazyk pritom nepoukazuje na konkrétne náboženstvo" (str. 83). Za vel'mi dôležité pre pochopenie dnešného antagonizmu na strane Grécka voči Macedónsku považujem pripomenutie aktivít macedónskeho obyvatel'stva a komunistickej strany Grécka v severnom Grécku v období počas a po ukončení 2. sv. vojny, ktoré presadzovali zjednotenie území Macedónska a Trácie v tzv. Balkánskej komunistickej federácii. Dôsledkom vít’azstva gréckej pravice v občianskej vojne bol masový útek macedónskeho obyvatel'stva na sever, resp. jeho vysídl'ovanie (str. 89), pričom $\mathrm{v}$ gréckom povedomí nad’alej pretrváva táto historická reminiscencia napriek tomu, že odvtedy sa na macedónskej strane neprejavili žiadne viditel'né známky skutočnej iredentistickej politiky (nacionalistickú propagandu typu Skopje 2014 za iredentu nepovažujem). Autor d’alej správne pripomína, že zmena pomeru medzi albánskou menšinou a macedónskou väčšinou nastáva až po vzniku Titovej Juhoslávie, a to v dôsledku albánskej migrácie z Kosova, resp. slabej natality Macedóncov.

Okrem toho sa autor venuje koreňom konfliktu medzi slovanským a albánskym obyvatel'stvom, resp. krest’ansko-moslimskému antagonizmu, a pripomína tak masové vyháňanie moslimov po Berlínskom kongrese, ako aj založenie Prizrenskej ligy, ktorá za etnicky albánske územia považovala napr. Skopje či Bitolu (str. 106). Samozrejmost’ou je zmienka o Londýnskej mierovej zmluve, ktorá odmietla maximalistické albánske požiadavky a zároveň ponechala vel'kú čast' Albáncov mimo novovzniknutého materského štátu (str. 111), čoho 
dôsledky sme pocítili po rozpade SFRJ v podobe separatistických albánskych hnutí v Kosove, južnom Srbsku a Macedónsku. Rosůlek tiež uvádza kontroverzné výroky S. Berishu z r. 1991, ktorý „podporoval svojich krajanov...v Macedónsku vo svojom úsilí zriadit' vlastný nezávislý štát" (str. 125), čo rozhodne neprispievalo k budovaniu dôvery medzi jednotlivými komunitami.

Nejde síce o vel'mi podstatný detail, trochu zvláštny je však popis prítomnosti albánskeho obyvatel'stva v regióne - zatial' čo autor pripomína historické pramene dokazujúce existenciu albánskych kmeňov na Balkáne od stredoveku (str. 84-85), $\mathrm{v}$ závere potom tvrdí, že „albánske etnikum sa v regióne vyskytovalo dávno pred príchodom slovanského živlu“, čo považuje za „t'ažko vyvrátitel’nú skutočnost"“ (str. 341). Hoci je pravdou, že vel'ká väčšina relevantných historických prác sa zhoduje na téze, že sa Albánci dajú považovat' za potomkov starovekých Ilýrov (tejto argumentácii odporujú prevažne srbskí historici, ktorých diela sú však často ovplyvnené antialbánskymi predsudkami; dobrý súhrn tejto problematiky prináša napr. Hradečný a Hladký 2008), pred 6. storočím - čiže pred príchodom Slovanov na Balkán - možno len t’ažko hovorit' o albánskom národe, resp. etniku. Okrem toho, $\mathrm{v}$ porovnaní $\mathrm{s}$ autorovou evidentnou erudíciou pri analýze macedónskoalbánskych vzt'ahov, mierne rozpačito pôsobí popis vývoja v Kosove. Rosůlek napr. uvádza, že „pre malý záujem Albáncov stroskotal pokus nacistov zostavit' divíziu SS Skanderbeg“ (str. 114). Je síce pravdou, že sa táto divízia stretávala s dezerciou a podobnými problémami, reálne však fungovala, a ako priznáva aj samotný autorov zdroj N. Malcolm (1998), zatknutie skoro troch stoviek prištinských Židov týmito jednotkami, ktorí boli následne poslaní do tábora Bergen-Belsen, je „najhanebnejšou epizódou vojnovej histórie Kosova“. Malcolmova kniha „Kosovo. A Short History“ je v tejto podkapitole jedným z klúčových zdrojov, jeho videnie je však do vel'kej miery proalbánske a viacerí jeho recenzenti (M. Glenny, T. Judah) ho kritizovali za nedostatočné využívanie srbských prameňov - je trochu škoda, že autor nevyužil napr. publikáciu V. Štěpánka (2011), ktorá sa dá označit' za vyváženejšiu.

Časti knihy popisujúce vývoj v krajine od r. 1991 sú spracované podrobne a čitatel' $\mathrm{v}$ nich nájde všetko potrebné pre utvorenie si koherentného obrazu o charaktere medzietnických vzt'ahov v Macedónsku. Autor sa vracia k prvým problémom vo vzájomnom súžití (rezervované vnímanie spoločného štátu od počiatku vrátane odmietnutia ústavy, protesty v Tetove, ilegálne referendum o autonómii, či kroky starostu Gostivaru) a výstižne konštatuje, že „albánske požiadavky na autonómiu...vyvolávali u väčšinového obyvatel'stva obavy, že sú prvým krokom k separatizmu, vedúcemu k odtrhnutiu západných častí krajiny a následnému pripojeniu k Albánsku či Kosovu“ (str. 139). Tieto obavy v každom prípade platia dodnes. Podhubie, v ktorom radikálni nacionalisti skandujú heslá „Albánci do plynu“ v dôsledku založenia Inštitútu pre výučbu albánskeho jazyka v r. 1997 (str. 145), je samozrejme vel'mi „prajné“ pre vypuknutie neskoršieho ozbrojeného konfliktu. Rosůlek tak vedie čitatela komplikovanými cestami 
vnútornej macedónskej politiky a albánskych požiadaviek, ktoré pod vplyvom dlhodobej absencie vzájomného pochopenia, niekol'kých skratkovitých rozhodnutí, ale tiež záujmov organizovaného zločinu rezultujú až do výbuchu $\mathrm{v} \mathrm{r}$. 2001. Voči vypuknutiu konfliktu je pritom kritický: „Napriek istým...deficitom v oblasti politickej i ekonomickej však...Albánci neboli ani zd’aleka $\mathrm{v}$ tak kritickej situácii, aby im pre presadzovanie svojich požiadaviek nezostávala iná možnost', než ozbrojený boj“" (str. 165).

Jedinou menšou výhradou je tu dost' malý priestor venovaný situácii v Albánsku v r. 1997, o ktorej autor iba konštatuje, že „pravdepodobne prispela ku kríze“ (str. 163). Je pritom otázne, či by bez zbraní, ktoré kosovská UÇK získala práve z rozkradnutých albánskych skladov, mohol kosovský konflikt, ktorý bol pre macedónsku UÇK zdrojom (nielen) inšpirácie, eskalovat' až do tak vel'kých rozmerov (zrov. Pettifer a Vickers 2007). Okrem toho autor konštatuje, že „obavy z albánskeho iredentizmu...sú pravdepodobne omnoho väčšie, než samotná túžba Albáncov po vytvorení všealbánskeho štátu“ (str. 163). Hoci je pravdou, že albánske politické subjekty otvorene presadzujúce projekt Vel'kého Albánska dodnes nemajú v regióne významnú podporu, bolo by vhodné takto jednoznačne formulované tvrdenie doložit' niektorými zdrojmi.

Obsahovo bohatá je tiež čast' venovaná postkonfliktnej situácii a implementácii jednotlivých častí Ohridskej rámcovej dohody (OFA), pričom autor kladie o.i. dostatočný dôraz na etnickú selektívnost' albánskeho postupu, ktorý existenciu d’alších menšín v krajine neberie príliš do úvahy. Pripomína tiež, že ciel západnej intervencie - zaviest' v krajine univerzálny občiansky princíp zlyháva už v samotnej OFA, ktorá jednotlivé „,communities“ vyčleňuje na základe etnicity. Zaujímavost'ou je téza, že OFA síce ukončila konflikt, avšak medzietnické vzt’ahy boli horšie, než pred jej uzatvorením (podobne tak stúpla frekvencia predčasných volieb), hoci skepsa na macedónskej strane, ktorá prirovnávala situáciu k Libanonu či Nigérii (str. 205), je zrejme prehnaná.

V záverečných kapitolách knihy si autor všíma rastúci nacionalizmus VMRO a správne konštatuje, že „poantičt’ovanie a trvanie na zachovaní ústavného názvu krajiny provokovali Albáncov, ktorí...by radšej uprednostnili vstup do EÚ a NATO“ (str. 272). Kontinuálne rastúce vnútorné napätie obzvlášt’ od gréckeho veta na summite v Bukurešti v r. 2008 viedlo až k pesimistickým predpovediam o zopakovaní scenára z r. 2001, pokial' budú macedónski Albánci vidiet' lepšiu budúcnost' mimo Macedónska. Tu mohol autor poskytnút' trochu viac priestoru analýze európskej perspektívy Macedónska, hoci chápem, že ide o tému idúcu do istej miery nad rámec publikácie. Vel’mi dobre je spracovaná tematika školstva a vzdelávania, kde dochádza $\mathrm{k}$ rastúcej separácii a prijímania selektívnych naratívov (str. 299).

Autor samozrejme nemôže za to, že v období ostatných dvoch rokov došlo $\mathrm{v}$ Macedónsku k významným zmenám, ktoré majú priamy vplyv i na medzietnické vzt’ahy, a ktoré v knihe už nie sú zachytené. Katastrofálne dopady vlády VMRO 
vrátane všetkých jej káuz na čele s odpočúvaním a faktickým „únosom štátu“ viedli o.i. $\mathrm{k}$ tomu, že albánski voliči v snahe ukončit' Gruevského éru vo väčšej miere hlasovali za SDSM, zatial' čo ešte v r. 2001 bola jej podpora medzi Albáncami na úrovni $0,86 \%$ (str. 221). Zmenil sa tiež stav, v ktorom „SDSM stráca stúpencov pre svoj ústretovejší postoj (k zmene názvu krajiny)“ (str. 288). Pre pochopenie situácie v krajine je Rosůlkova kniha vel'mi dobrou investíciou, no je pravdepodobné, že v blízkej budúcnosti sa môžu niektoré veci rýchlo menit', a to oboma smermi v závislosti od úspechov Zaevovej vlády. Netreba zabúdat', že niekdajší premiér Lj. Georgievski už po ukončení ozbrojených bojov navrhoval teritoriálne rozdelenie Macedónska tak, aby „boli zachránené mestá Kumanovo, Skopje, Kičevo a Struga“ (str. 257), čo svedčí o stále slabej štátnej integrite a nedôvere vo vlastné (politické) sily. Stále platí, že „postkomunizmus s d’alšími faktormi ako nacionalizmus, nevýhodná geografická poloha a absencia demokratických tradícií predstavuje vel'ké bremeno na ceste priblíženia sa $\mathrm{k}$ demokratickej Európe“ (str. 261). Pred autorom tak rozhodne bude stát' d’alšia výzva v podobe druhého dielu - vývoj v r. 2014 - ?

\section{Literatura:}

Malcolm, Noel (1998): Kosovo. A Short History. Londýn: MacMillan.

Hradečný, Pavel a Ladislav Hladký (2008): Déjiny Albánie. Praha: Nakladatelství Lidové Noviny.

Pettifer, James a Miranda Vickers (2007): The Albanian Question: Reshaping the Balkans. Londýn: I.B.Tauris.

Štěpánek, Václav (2011): Jugoslávie-Srbsko-Kosovo. Kosovská otázka ve 20. století. Brno: Masarykova univerzita. 